\title{
Bodies of Difference
}




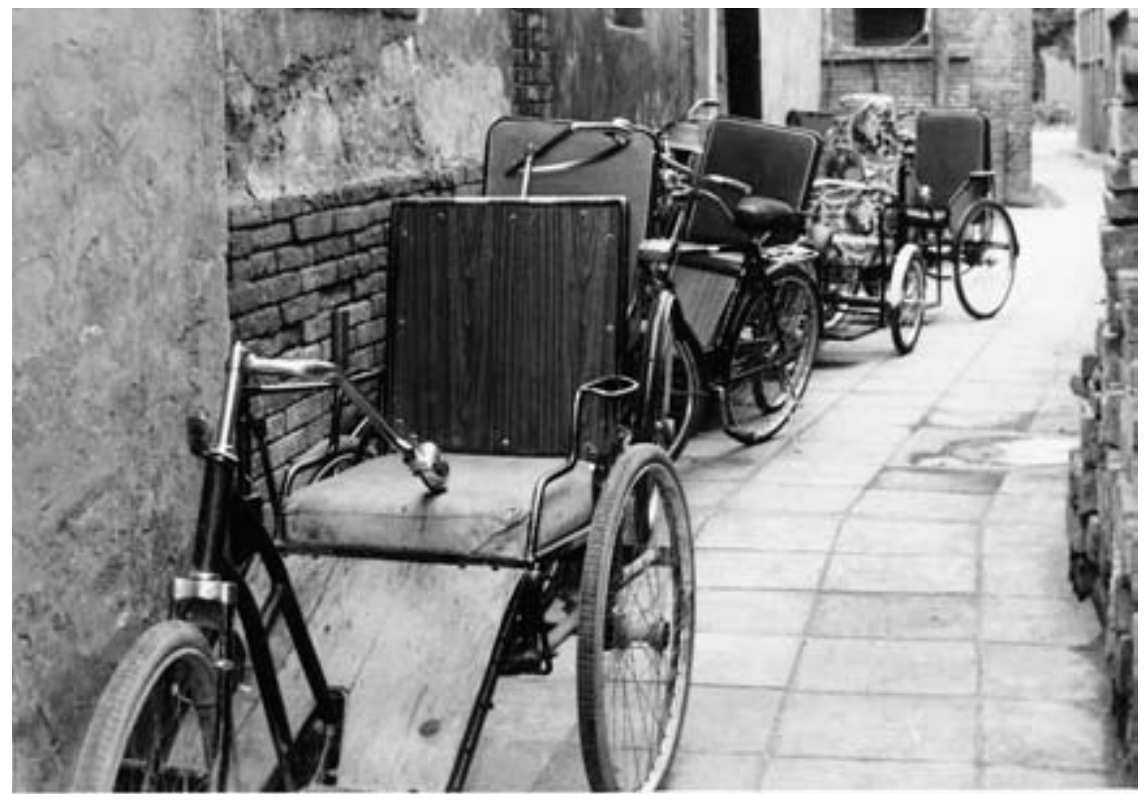

Hand-crank tricycles mark a gathering of the Beijing Disabled Youths Club at the home of a former club member, mid-1980s. Anonymous photo. 


\title{
Bodies of Difference
}

Experiences of Disability and Institutional Advocacy in the Making of Modern China

\author{
Matthew Kohrman
}

UNIVERSITY OF CALIFORNIA PRESS

Berkeley Los Angeles London 
University of California Press

Berkeley and Los Angeles, California

University of California Press, Ltd.

London, England

(C) 2005 by the Regents of the University of California

Library of Congress Cataloging-in-Publication Data

Kohrman, Matthew, 1964-.

Bodies of difference : experiences of disability and institutional advocacy in the making of modern China / Matthew Kohrman.

p. $\mathrm{cm}$.

Includes bibliographical references and index.

ISBN 0-520-22644-5 (cloth : alk. paper) —ISBN 0-520-22645-3

(pbk. : alk. paper)

1. People with disabilities-China. 2. Biopolitics - China.

I. Title.

нV1559.С6к64 2005

$3^{62.4^{\prime}} 095^{1-\operatorname{dc} 22}$

$2004005^{2} 79$

Manufactured in the United States of America

$\begin{array}{lllllllll}13 & 12 & 11 & 10 & 09 & 08 & 07 & 06 & 05\end{array}$

$\begin{array}{llllllllll}10 & 9 & 8 & 7 & 6 & 5 & 4 & 3 & 2 & 1\end{array}$

Printed on Ecobook $5^{\circ}$ containing a minimum $5^{\circ} \%$ post-consumer waste, processed chlorine free. The balance contains virgin pulp, including 25\% Forest Stewardship Council Certified for no old growth tree cutting, processed either TCF or ECF. The sheet is acid-free and meets the minimum requirements of ANSI/NISO z39.48-1992 (R 1997) (Permanence of Paper).@ 
For Asa and Ezra 
